\title{
Effects of 2-diethylaminoethyl-3,4- dichlorophenylether on cadmium tolerance and accumulation of an energy plant, hemp (Cannabis sativa L.)

\author{
Gangrong Shi ${ }^{\mathrm{a}^{*}}$, Caifeng Liu ${ }^{\mathrm{b}}$, Zheng Zhang ${ }^{\mathrm{c}}$ \\ College of Life Sciences, Huaibei Normal University, Huaibei, 235000, P. R. China \\ . ${ }^{\mathrm{a}}$ swsgr@126.com, ${ }^{\mathrm{b}}$ liucaifen2006@126.com, ${ }^{\mathrm{c}} \mathrm{hbzhzhxyy@126.com}$
}

Keywords: Cadmium; hemp; 2-(3,4-dichloro-phenoxy)-triethylamine; tolerance; accumulation Abstract This study was undertaken to determine whether 2-(3,4-dichlorophenoxy)-triethylamine (DCPTA) improve plant growth of Cd-exposed hemp (Cannabis sativa L.) plants. The results showed that exposure of plants to $50 \mathrm{mg} \mathrm{Cd} \mathrm{kg}$ soil resulted in an increase in the shoot and root biomass, as well as the root/shoot ratio. These results confirmed that hemp is a Cd-tolerance plant species, and it is possible to culture hemp in $\mathrm{Cd}$ contaminated farmlands for bioenergy production. Single application of 10-50 $\mathrm{mg} \mathrm{L}^{-1}$ DCPTA increased biomass production in hemp seedlings. When DCPTA and Cd were used simultaneously, they increased the root biomass in a dose-dependent manner. Moreover, DCPTA application caused an increase in root $\mathrm{Cd}$ content and the total $\mathrm{Cd}$ in the root, and there is a positive correlation between biomass and $\mathrm{Cd}$ accumulation in the root.

\section{Introduction}

Cadmium $(\mathrm{Cd})$ is a widespread toxic heavy metal that usually causes deleterious effects in living organisms. Soil pollution with $\mathrm{Cd}$ is especially serious when they are used for crop cultivation, since $\mathrm{Cd}$ is easily taken up by plant roots and enters into the food chain, threatening human and animal health [1]. Therefore, how to reduce $\mathrm{Cd}$ risks has been an important issue for environment scientists.

There are several options available to reduce Cd risks to human health. One is to immobilization or extraction by physicochemical techniques, which are highly effective and clear-cutting but too expensive [2]. Although phytoremediation has been considered as a novel remediation technique that is low-cost and environment-friendly compared with the traditional ways, its application is still very limited due to low biomass of hyperaccumulators, unavailability of the suitable plant species and unprofitable production during remediation [3].

Hemp (Cannabis sativa L.) is a multiple-use plant, widely employed in many types of non-food industries and providing raw materials for the production of natural fiber, insulating board, rope, oil, varnish and paper [4]. It has been recently considered as an energy crop, from which the biomass used as fuel, or the seed oil for bio-diesel production [5]. Several studies indicated that hemp is a metal-tolerant organism, and the amount of $\mathrm{Cd}$ accumulated in its shoot was not negligible [6-8]. In this regard, we have postulated a new strategy of cultivating hemp plants in Cd-contaminated soils for bioenergy production, and this can be combined with long-term gradual attenuation of the contaminants.

The 2-(3,4-dichlorophenoxy)-triethylamine (DCPTA), a group of plant growth regulators, have been demonstrated to increase productivity in several plants, such as soybean [9], cotton [10], tomato [11] and eggplant [12]. Foliar application of DCPTA significantly increased the taproot development, leaf development, and the photosynthetic productivity of sugar beet [13]. In this context, we hypothesized that DCPTA might confer resistance to plants against Cd stresses. The purpose of this study was to test the hypothesis that hemp might be a good candidate for bioenergy production in Cd-contaminated soils, and DCPTA might improve growth in Cd-exposed hemp plants. 


\section{Materials and methods}

Experimental set-up. Two runs of the pot experiment were carried out in a growth chamber in the year 2010 and 2011 respectively. The conditions of growth chamber were: the light intensity, 650 $\mu \mathrm{mol} \mathrm{m} \mathrm{m}^{-2} \mathrm{~s}^{-1}$; day/night cycle, $14 / 8 \mathrm{~h}$; average temperature (day/night), $26 \pm 1{ }^{\circ} \mathrm{C} / 23 \pm 1{ }^{\circ} \mathrm{C}$; the relative humidity (day/night), 48-66\%/53-71\%. The soil type was gravel blackland soil (sand: silt: clay; $23.8 \%$ : 20.3\%: $55.9 \%$ ), which is characterized as: $\mathrm{pH}, 7.24 ; \mathrm{N}, 68.4 \mathrm{mg} \mathrm{kg}^{-1} ; \mathrm{P}_{2} \mathrm{O}_{5}, 9.36 \mathrm{mg}$ $\mathrm{kg}^{-1} ; \mathrm{K}_{2} \mathrm{O}, 75.3 \mathrm{mg} \mathrm{kg}^{-1}$; organic matter, $1.12 \%$; electrical conductivity, $23.6 \mu \mathrm{s} \mathrm{cm}^{-1}$; $\mathrm{Cd}, 0.126$ $\mathrm{mg} \mathrm{kg}^{-1}$. Three levels of Cd $\left(0,25,50 \mathrm{mg} \mathrm{Cd} \mathrm{kg}^{-1}\right.$ soil) and four levels of DCPTA $(0,10,50,100$ $\mathrm{mg} \mathrm{L}^{-1}$ ) were arranged in a randomized complete block design, giving a total of twelve treatments. Seeds of hemp (C. sativa cv. longxi) were sown in the pot $(16 \mathrm{~cm} \times 18 \mathrm{~cm})$ filled with $3 \mathrm{~kg}$ of soils. Three pots with eight plants per pot were prepared for each treatment. Cd was included in soil as $\mathrm{CdCl}_{2} \cdot 2.5 \mathrm{H}_{2} \mathrm{O}$ by spraying the solutions and thoroughly mixed. The pots were watered daily to $60 \%$ of water-holding capacity. When the seedlings had three mature leaves, they were sprayed with different concentrations of DCPTA. After $25 \mathrm{~d}$ of growing, when plants of the control have five mature leaves, physiological variables were determined.

Evaluation of plant growth and Cd accumulation. The plants were washed with running tap water and rinsed with deionized water to remove any soil particles attached to the plant surfaces. The roots and shoots were separated and oven-dried for $30 \mathrm{~min}$ at $105^{\circ} \mathrm{C}$, then at $65^{\circ} \mathrm{C}$, until they reached constant weights. The dried tissues were weighed and ground into a powder. $\mathrm{Cd}$ concentrations were measured using flame atomic absorbance spectrometry after digestion with mixed acid $\left[\mathrm{HNO}_{3}+\mathrm{HClO}_{4}(3: 1, \mathrm{v} / \mathrm{v})\right]$.

The translocation factor (TF) and total $\mathrm{Cd}$ in plant tissues were calculated as follows [14]:

$\mathrm{TF}=[\mathrm{Cd}]_{\text {shoot }} /[\mathrm{Cd}]_{\text {root }}$

Total $\mathrm{Cd}$ in plant tissues $=[\text { biomass }]_{\text {shoot or root }} \times[\mathrm{Cd}]_{\text {shoot or root }}$

Statistical analysis. Data obtained from two runs of the experiment were subjected to a two-way analysis of variance (ANOVA) using SPSS Version 13.0 software (SPSS Inc., USA), where DCPTA and Cd treatment were modeled as fixed factors, with their interaction $(\mathrm{Cd} \times \mathrm{DCPTA})$.

\section{Results and discussion}

Plant growth. Growth inhibition and reduction of biomass production are general responses of higher plants to $\mathrm{Cd}$ toxicity [15]. Thus, the growth rate and biomass have been widely used to evaluate metal toxicity to plants. Controversially, the present work showed that long-term growth with 25 and $50 \mathrm{mg} \mathrm{kg}^{-1} \mathrm{Cd}$ produced an increase in the shoot and root biomass in hemp plants (Fig. 1). This phenomenon, termed as hormesis effect, have been observed previously in the same species [3]. By contrast, the increase of root biomass (138.6\%) under $50 \mathrm{mg} \mathrm{Cd} \mathrm{kg}$ soil condition was more pronounced than that of shoot biomass $(21.7 \%)$, thus leading to a dramatic increase in the root/shoot ratio (Fig. 1). The shoot height remained unaffected. The present data, in accordance to the previous studies [6-8], suggest that hemp is a Cd-tolerance plant species, which can cope with high external concentrations of $\mathrm{Cd}$ without showing any visible toxicity symptom. 

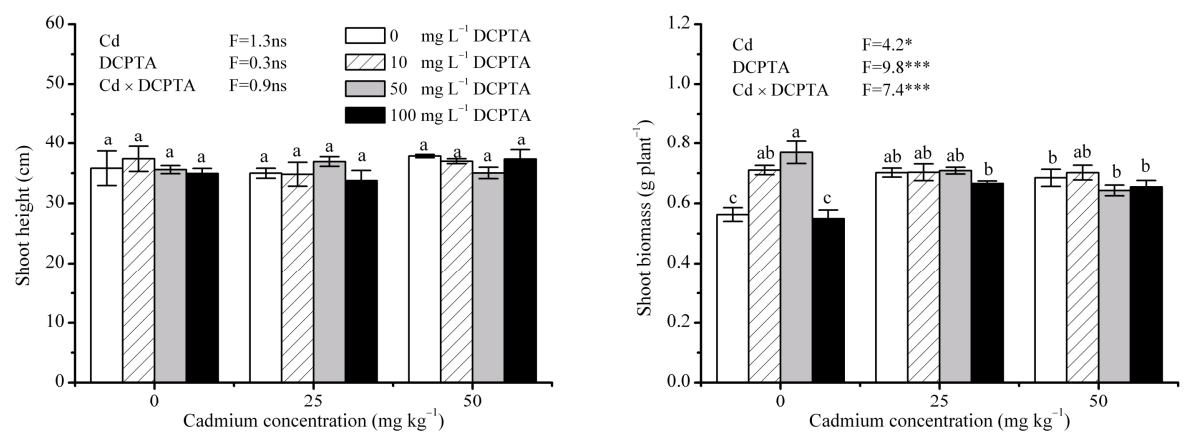

(a)
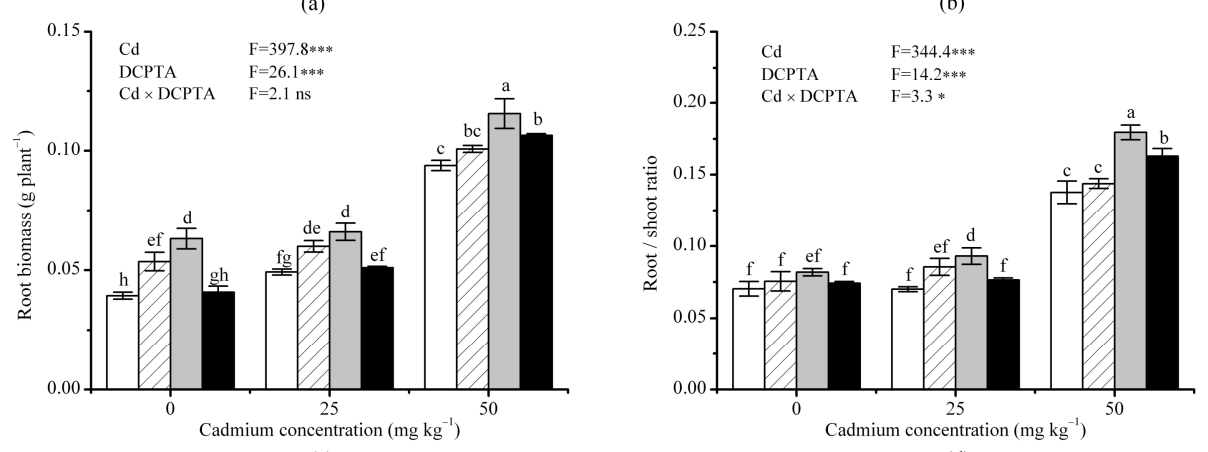

(c)

(d)

Fig. 1. Effects of Cd and DCPTA on shoot height (a), shoot biomass (b), root biomass (c), and root/shoot ratio (d) in hemp plants. The different letters above the error bars represent the mean values $(n=6)$ are significantly different according to the Duncan's test $(\mathrm{P}<0.05)$. ns: not significant, $* * * \mathrm{P}<0.001$.

DCPTA applied alone caused a dose-dependent enhancement in the growth of hemp plants, measured as dry biomass of roots and shoots (Fig. 1). In comparison to the control, application with 10 and $50 \mathrm{mg} \mathrm{L}^{-1}$ DCPTA promoted biomass accumulation in shoot and root, whereas in $100 \mathrm{mg}$ $\mathrm{L}^{-1}$ DCPTA, they were not affected. Similar results have been reported by several authors [10-13].

One of the interesting findings of the present study is that, foliar application of DCPTA to Cd-exposed hemp seedlings resulted in an additive effect in root growth. This was depended on both DCPTA and Cd concentrations. When the plants were exposed to $25 \mathrm{mg} \mathrm{kg}^{-1} \mathrm{Cd}$ soils, the root biomass and the root/shoot ratio were significantly enhanced by 10 and $50 \mathrm{mg} \mathrm{L}^{-1}$ DCPTA, while at $50 \mathrm{mg} \mathrm{kg}^{-1} \mathrm{Cd}$ treatment, they were increased by 50 and $100 \mathrm{mg} \mathrm{L}^{-1}$ DCPTA (Fig. 1). There were significant $\mathrm{Cd} \times$ DCPTA interactions on the shoot biomass $(\mathrm{p}<0.001)$ and the root/shoot ratio $(\mathrm{p}<0.05)$.

Cd accumulation and distribution. The shoot $\mathrm{Cd}$ content and total $\mathrm{Cd}$ accumulated in shoot by plants were similar in different Cd and DCPTA treatments $(p>0.05)$, as outlined in Table 1. However, the root $\mathrm{Cd}$ content showed a tendency of increment with the increasing of soil $\mathrm{Cd}$ concentrations, resulting in an enhancement of the total $\mathrm{Cd}$ in the root, and a decrease of translocation factors $(T F \mathrm{~s})$ (Table 1).

It has been suggested that plants can be intoxicated when soil total $\mathrm{Cd}$ concentration is greater than $8 \mathrm{mg} \mathrm{kg}^{-1}$, or soluble (bioavailable) Cd concentration is more than $0.001 \mathrm{mg} \mathrm{kg}^{-1}$, or tissue Cd concentration reaches $3-10 \mathrm{mg} \mathrm{kg}^{-1} \mathrm{DW}$ [16]. In the present study, the Cd content in the shoot and root of hemp plants was more than 19 and $184 \mathrm{mg} \mathrm{kg}^{-1}$ respectively (Table 1). The soil total Cd concentrations applied here were 25 and $50 \mathrm{mg} \mathrm{kg}^{-1}$. Such a dose is far higher than doses commonly encountered, even in heavily polluted farmland soils. According to Li et al. [17], the mean $\mathrm{Cd}$ concentration in the 0-20cm soil layer in Zhangshi irrigation area (Shenyang, China, ceased in 1992) is still $1.75 \mathrm{mg} \mathrm{kg}^{-1}$ and the highest $\mathrm{Cd}$ value is up to $10 \mathrm{mg} \mathrm{kg}^{-1}$ in some sampling points. The obtained result suggest that it is possible to culture hemp in Cd contaminated farmlands for bioenergy production. 
Table 1 Effects of Cd and DCPTA on Cd content in plant tissues, total Cd in plant tissues, and translocation factor $(T F)$ of hemp plants.

\begin{tabular}{|c|c|c|c|c|c|}
\hline \multirow[t]{2}{*}{ Treatments } & \multicolumn{2}{|c|}{$\begin{array}{l}\text { Cd content in plant tissues } \\
\left(\mu \mathrm{g} \mathrm{g}^{-1}\right)\end{array}$} & \multicolumn{2}{|l|}{ ( $\mu \mathrm{g}$ plar } & \multirow[t]{2}{*}{$\begin{array}{l}\text { Translocation } \\
\text { factor }\end{array}$} \\
\hline & Shoots & Roots & Shoots & Roots & \\
\hline \multicolumn{6}{|l|}{$25 \mathrm{mg} \mathrm{kg}^{-1} \mathrm{Cd}$} \\
\hline $0 \mathrm{mg} \mathrm{L}^{-1}$ DCPTA & $19.4 \pm 2.1 \mathrm{a}$ & $184.2 \pm 3.8 \mathrm{~d}$ & $15.0 \pm 2.9 \mathrm{a}$ & $10.2 \pm 1.6 \mathrm{~d}$ & $0.105 \pm 0.010 \mathrm{a}$ \\
\hline $10 \mathrm{mg} \mathrm{L}^{-1}$ DCPTA & $19.9 \pm 0.5 \mathrm{a}$ & $182.9 \pm 8.7 \mathrm{~d}$ & $13.5 \pm 1.2 \mathrm{a}$ & $10.6 \pm 1.1 \mathrm{~d}$ & $0.109 \pm 0.005 \mathrm{a}$ \\
\hline $50 \mathrm{mg} \mathrm{L}^{-1}$ DCPTA & $22.3 \pm 1.9 \mathrm{a}$ & $232.7 \pm 5.2 \mathrm{c}$ & $15.3 \pm 2.1 \mathrm{a}$ & $14.7 \pm 1.2 \mathrm{~d}$ & $0.096 \pm 0.006 \mathrm{ab}$ \\
\hline $\begin{array}{l}100 \quad \mathrm{mg} \\
\text { DCPTA }\end{array}$ & $24.6 \pm 1.7 \mathrm{a}$ & $277.3 \pm 17.2 \mathrm{c}$ & $17.4 \pm 1.9 \mathrm{a}$ & $16.6 \pm 3.1 \mathrm{~d}$ & $0.089 \pm 0.001 b$ \\
\hline $50 \mathrm{mg} \mathrm{kg}^{-1} \mathrm{Cd}$ & & & & & \\
\hline $0 \mathrm{mg} \mathrm{L}^{-1}$ DCPTA & $19.6 \pm 0.9 \mathrm{a}$ & $407.6 \pm 5.1 \mathrm{~b}$ & $13.5 \pm 1.0 \mathrm{a}$ & $38.2 \pm 0.5 b c$ & $0.048 \pm 0.003 c$ \\
\hline $10 \mathrm{mg} \mathrm{L}^{-1}$ DCPTA & $21.5 \pm 1.3 \mathrm{a}$ & $436.4 \pm 10.6 \mathrm{ab}$ & $13.9 \pm 1.3 \mathrm{a}$ & $29.4 \pm 1.7 \mathrm{c}$ & $0.049 \pm 0.003 \mathrm{c}$ \\
\hline $50 \mathrm{mg} \mathrm{L}^{-1}$ DCPTA & $20.2 \pm 0.9 \mathrm{a}$ & $468.7 \pm 15.2 \mathrm{a}$ & $12.1 \pm 1.3 \mathrm{a}$ & $44.7 \pm 5.6 b$ & $0.043 \pm 0.003 \mathrm{c}$ \\
\hline $\begin{array}{l}100 \quad \mathrm{mg} \\
\text { DCPTA }\end{array}$ & $21.2 \pm 0.3 \mathrm{a}$ & $471.5 \pm 33.1 \mathrm{a}$ & $15.4 \pm 1.2 \mathrm{a}$ & $55.5 \pm 5.3 \mathrm{a}$ & $0.045 \pm 0.003 \mathrm{c}$ \\
\hline ANOVA & & & & & \\
\hline $\mathrm{Cd}$ & $0.9 \mathrm{~ns}$ & $438.8 * * *$ & $1.7 \mathrm{~ns}$ & $174.8 * * *$ & $232.3 * * *$ \\
\hline DCPTA & $2.2 \mathrm{~ns}$ & $11.3 * * *$ & $1.1 \mathrm{~ns}$ & $10.1 * *$ & $2.7 \mathrm{~ns}$ \\
\hline $\mathrm{Cd} \times$ DCPTA & $1.4 \mathrm{~ns}$ & $1.3 \mathrm{~ns}$ & $0.4 \mathrm{~ns}$ & $3.5 *$ & $1.1 \mathrm{~ns}$ \\
\hline
\end{tabular}

Values (mean \pm S.E., $n=6$ ) with different letters in the same column are significantly different according to the Duncan's test $(\mathrm{P}<0.05)$.

It is well known that some plants, namely excluders, can grow in heavy metal polluted soils without accumulating significant quantities. In this study, most of $\mathrm{Cd}$ absorbed by plant was retained in the root, although the capacity to accumulate this metal depends on the Cd concentration in the soil. The TFs were only ranged from 0.048 to 0.105 (Table 1), showing a strong limitation of $\mathrm{Cd}$ translocation from the root to shoot. Therefore, hemp can be considered as a Cd excluder, which is unsuitable for phytoextraction alone. Despite this, the total $\mathrm{Cd}$ in shoot were ranged from 13.5 to $15.0 \mu$ plant $^{-1} \mathrm{DW}$ in 25-d-old seedlings. Such amount of $\mathrm{Cd}$ accumulated in shoot may not be negligible, since hemp is a high biomass species with a rapid development [6], especially in the practice of combination phytoextraction with bioenergy production.

Interestingly, foliar application of DCPTA caused an increase in root Cd content and the total $\mathrm{Cd}$ in the root; this was found to be a dose-dependent, and it was also depending on Cd levels the plants subjected. By contrast, DCPTA-induced Cd accumulation in the root was more pronounced in $50 \mathrm{mg} \mathrm{kg}{ }^{-1} \mathrm{Cd}$ soils than in $25 \mathrm{mg} \mathrm{kg}^{-1} \mathrm{Cd}$ soils (Table 1). The shoot $\mathrm{Cd}$ contents were not affected by DCPTA application (Table 1). The effect of DCPTA on Cd accumulation is most probably indirect (since DCPTA is supplied by foliar spraying). Possible causes of DCPTA-stimulated Cd accumulation in roots include: a) stimulation of root growth, thus lead to an increase of absorption area; b) activation of some divalent cation transporter capable of bind $\mathrm{Cd}$, and c) enhanced $\mathrm{Cd}$ ion immobilization in the root intercellular spaces or in the vacuole.

More importantly, the present study showed that there is a positive correlation between biomass and $\mathrm{Cd}$ accumulation in the root $(\mathrm{p}<0.001)$ (Fig. 2). This finding is surely inconsistent with the results from other studies [18,19], where the biomass decreased with the increasing of $\mathrm{Cd}$ accumulation. The reason may be that the root $\mathrm{Cd}$ content is lower than the critical content which caused an inhibition of root biomass production, and there is a hormesis effect existed in $\mathrm{Cd}$ and plant interactions. In a sand culture experiment, Shi et al. [3] found that the root biomass was similar to control even the Cd content reached $1,115 \mathrm{mg} \mathrm{kg}^{-1}$ at $25 \mathrm{mg} \mathrm{kg}^{-1} \mathrm{Cd}_{\text {treatment. }}$ 


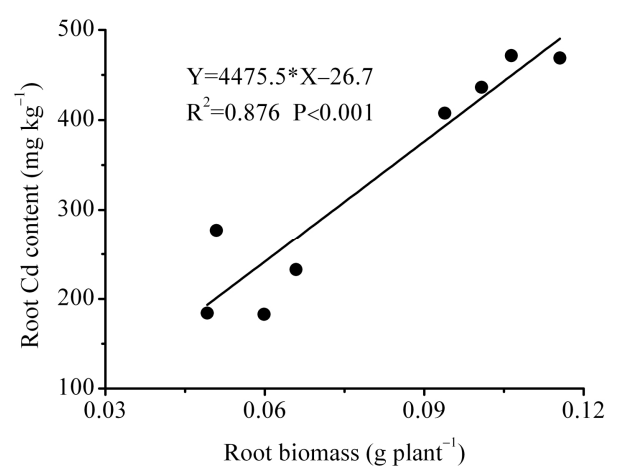

Fig. 2. Relationship between root Cd content and root biomass.

\section{Summary}

In conclusion, hemp is a Cd-tolerance plant species, and it is possible to culture hemp in $\mathrm{Cd}$ contaminated farmlands for bioenergy production. DCPTA without $\mathrm{Cd}$ increases biomass production in dose-dependent manner. DCPTA with Cd resulted in an increase biomass production and $\mathrm{Cd}$ accumulation in the root of hemp. However, DCPTA does not improve shoot growth in Cd-exposed hemp plants.

\section{References}

[1] W. Liu, Q. Zhou, J. An, Y. Sun, R. Liu, Variations in cadmium accumulation among Chinese cabbage cultivars and screening for Cd-safe cultivars. J Hazard Mater 173 (2010) 737-743.

[2] I.D. Pulford, C. Watson, Phytoremediation of heavy metal-contaminated land by trees-a review. Environ Int 29 (2003) 529-540.

[3] G. Shi, Q. Cai, Cadmium tolerance and accumulation in eight potential energy crops. Biotechnol Adv 27 (2009) 555-561.

[4] P. Ranalli, Current status and future scenarios of hemp breeding. Euphytica 140 (2004) 121-131.

[5] X.A. Casas, J. Rieradevall i Pons, Environmental analysis of the energy use of hemp-analysis of the comparative life cycle: diesel oil vs. hemp-diesel. International Journal of Agricultural Resources, Governance and Ecology 4 (2005) 133-139.

[6] S. Citterio, A. Santagostino, P. Fumagalli, N. Prato, P. Ranalli, S. Sgorbati, Heavy metal tolerance and accumulation of Cd, Cr and Ni by Cannabis sativa L. Plant Soil 256 (2003) 243-252.

[7] G. Shi, Q. Cai, Q. Liu, L. Wu, Salicylic acid-mediated alleviation of cadmium toxicity in hemp plants in relation to cadmium uptake, photosynthesis, and antioxidant enzymes. Acta Physiol Plantarum 31 (2009) 969-977.

[8] P. Linger, A. Ostwald, J. Haensler, Cannabis sativa L. growing on heavy metal contaminated soil: growth, cadmium uptake and photosynthesis. Biol Plant 49 (2005) 567-576.

[9] H. Yokoyama, C. DeBenedict, W.J. Hsu, E. Hayman, Bioregulation of lipid and protein synthesis in soybean by 2-diethylaminoethyl-3, 4-dichlorophenylether. Nat Biotechnol 2 (1984) 712-714.

[10] H.W. Gausman, J.D. Burd, J. Quisenberry, H. Yokoyama, R. Dilbeck, C.R. Benedict, Effect of 2-diethylaminoethyl-3, 4-dichlorophenylether (DCPTA) on cotton plant (Gossypium hirsutum) growth and phenology. Nat Biotechnol 3 (1985) 255-257.

[11] J.H. Keithly, H. Yokoyama, H. Gausman, Enhanced yield of tomato in response to 2-(3, 4-dichlorophenoxy) triethylamine (DCPTA). Plant Growth Regul 9 (1990) 127-136.

[12] H. Kobayashi, J.H. Keithly, H. Yokoyama, Improvements in the fruit set and harvest index of eggplant by 2-(3, 4-dichlorophenoxy) triethylamine hydrochloride [DCPTA]. J. Japan. Soc. Hort. Sci 60 (1991) 77-81.

[13] J.H. Keithly, H. Yokoyama, H.W. Gausman, Effect of 2-(3, 4-dichlorophenoxy) triethylamine (DCPTA) on the growth and development of sugarbeet. Plant Sci 68 (1990) 57-64. 
[14] V.M.J. Grispen, H.J.M. Nelissen, J.A.C. Verkleij, Phytoextraction with Brassica napus L.: A tool for sustainable management of heavy metal contaminated soils. Environ Pollut 144 (2006) 77-83.

[15] M. Benavides, M.S. Gallego, M.L. Tomaro, Cadmium toxicity in plants. Braz J Plant Physiol 17 (2005) 21-34.

[16] M. Ghosh, S.P. Singh, A comparative study of cadmium phytoextraction by accumulator and weed species. Environ Pollut 133 (2005) 365-371.

[17] P. Li, X. Wang, G. Allinson, X. Li, X. Xiong, Risk assessment of heavy metals in soil previously irrigated with industrial wastewater in Shenyang, China. J Hazard Mater 161 (2009) 516-521.

[18] G. Shi, C. Liu, Q. Cai, Q. Liu, C. Hou, Cadmium accumulation and tolerance of two safflower cultivars in relation to photosynthesis and antioxidantive enzymes. Bull Environ Contam Toxicol 85 (2010) 256-263.

[19] A. Krantev, R. Yordanova, T. Janda, G. Szalai, L. Popova, Treatment with salicylic acid decreases the effect of cadmium on photosynthesis in maize plants. J Plant Physiol 165 (2008) 920-931. 